\title{
An Exposure Assessment of Arsenic and Other Trace Elements in Ha Nam Province, Northern Vietnam
}

\author{
Manh Ha Nguyen (i), ${ }^{1}$ Quoc Anh Hoang, ${ }^{1}$ Lan Anh Nguyen, ${ }^{1}$ Thi Thao Ta, ${ }^{1}$ \\ Tien Duc Pham $\mathbb{D}^{1}{ }^{1}$ Minh Binh Tu, ${ }^{1}$ and Dinh Binh Chu $\mathbb{D D}^{2}$ \\ ${ }^{1}$ Faculty of Chemistry, VNU University of Science, Vietnam National University, 19 Le Thanh Tong, Hoan Kiem, \\ Hanoi 100000, Vietnam \\ ${ }^{2}$ School of Chemical Engineering, Hanoi University of Science and Technology, 1 Dai Co Viet, Hai Ba Trung, \\ Hanoi 100000, Vietnam
}

Correspondence should be addressed to Manh Ha Nguyen; manhhath@gmail.com and Dinh Binh Chu; binh.chudinh@hust.edu.vn Received 19 September 2019; Revised 10 November 2019; Accepted 9 December 2019; Published 21 December 2019 Academic Editor: Richard G. Brereton

Copyright (c) 2019 Manh Ha Nguyen et al. This is an open access article distributed under the Creative Commons Attribution License, which permits unrestricted use, distribution, and reproduction in any medium, provided the original work is properly cited.

\begin{abstract}
Concentrations of As and other trace elements were measured in groundwater, rice, hair, urine, and blood samples of people consuming As-contaminated groundwater in a village of Ha Nam province, northern Vietnam to understand the recent status of contamination and assess the possible risks of human exposure. Elevated concentrations of As in groundwater were still observed, exceeding the WHO guideline value in most of the tube wells investigated. Significant positive correlations between As concentrations in groundwater and human samples (hair and urine) were observed. Arsenic concentrations in human and hair appeared to be related to the groundwater usage habit, with higher levels found in drinking group than those in the washing group. Significant good correlations were also encountered between cumulative intakes of As, Mn, and Ba through groundwater consumption and hair concentrations. All these results indicate the chronic exposure to As and some other elements such as $\mathrm{Mn}$ and $\mathrm{Ba}$. The total intakes of $\mathrm{As}, \mathrm{Mn}$, and $\mathrm{Ba}$ through rice and groundwater consumption were estimated to be ranged from $80-836,49.3-1850$, and $311-97100 \mu \mathrm{g} /$ day, respectively. The daily intakes of As of the study area ranged from $1.6-16.7 \mu \mathrm{g} / \mathrm{kg}$ body wt./day, mean: $7.15 \mu \mathrm{g} / \mathrm{kg}$ body wt./day, in which about $85 \%$ of the subjects were above the provisional tolerable daily intake proposed by WHO.
\end{abstract}

\section{Introduction}

In recent years, natural contamination by arsenic in groundwater has received considerable attention in many countries around the world such as India, Bangladesh, Chile, and Taiwan [1-4]. In Vietnam, the issue of arsenic contamination in groundwater and drinking water was discovered in 2001, in which elevated As concentrations were found in various areas in the Red River Delta, northern Vietnam [5]. Human exposure studies have been continuously conducted, and results indicated widespread contamination in both the Red River Delta in the north and Mekong River Delta in the south of Vietnam (review by
Agusa et al. [6]). Chronic exposure to arsenic from Ascontaminated groundwater has been suggested as main sources of human exposure. Severe arsenic poisoning symptom in Vietnam has also been reported [7, 8].

Most of the studies on human exposure to Arsenic in Vietnam have focused on the measurement of As in human hair and urine and very limited information on the levels of As in blood serum samples [6]. While many studies have been conducted, a comprehensive data set on the levels of As and other trace elements in paired tube-well water, human samples, and food sources in As-contaminated areas in Vietnam is still very limited. Such information is necessary for an in-depth evaluation of the extent of As contamination 
and risk for As exposure through drinking water and other intake sources.

In this study, we conducted a survey to collect groundwater from tube-wells of families in a village of $\mathrm{Ha}$ Nam province, northern Vietnam, where high and widespread contamination of As has recently been reported [9]. In addition, human samples (hair, urine, and serum) and rice samples from these families were also collected and concentrations of As and other trace elements were measured in order to provide a comprehensive assessment of the recent contamination status, human exposure, and risk assessment based on the intake doses of As consumption through rice and contaminated groundwater.

\section{Materials and Methods}

2.1. Sample Collection and Storage. Groundwater samples were randomly collected from 21 families in Nhat Tan villages, Ha Nam province, northern Vietnam during September 2018. Information of groundwater and human samples is given in Table 1 . In each family, unfiltered and sand filtered, or rainy water samples were simultaneously collected. Polypropylene bottles $(100 \mathrm{~mL})$, which were washed with Milli-Q water, were used for water sampling. The collected groundwater samples were acidified $(\mathrm{pH}<2)$ with extrapure $\mathrm{HCl}$ for $\mathrm{As}$ and $\mathrm{HNO}_{3}$ for other elements and stored at $-5^{\circ} \mathrm{C}$ as immediately as possible.

Human samples including urine, hair, and serum samples were also collected from the same families with groundwater collection. Our questionnaire survey indicates that there are two main groups of human samples, according to the habit of groundwater usage. One group uses groundwater for drinking, and the other uses it mainly for washing. Food consumption items of the people in the surveyed village are mainly rice, vegetables, egg, and pork. Spot urine samples were collected in a plastic tube (Tube Traite, $50 \mathrm{~mL}$, NJ, USA) and then stored at $4^{\circ} \mathrm{C}$ for storage and transported to the laboratory and analyzed immediately. Blood samples were taken with disposable needles inserted into the plastic tubes (Tube Traite, NJ, USA) after clotting the sera. After that, the collected sera samples were kept at $4^{\circ} \mathrm{C}$ and then transported to the laboratory immediately within a day; other sera samples were stored at $-18^{\circ} \mathrm{C}$. Hair and rice samples were kept in a zipped plastic bag and stored in a dry chamber at $20^{\circ} \mathrm{C}$ until analysis. Prior to the analysis, all rice samples were transferred into open, precleaned, and preweighed plastic tubes. Informed consent of all donors for using human samples for environmental exposure research was obtained.

2.2. Chemical Analyses. All single-element stock standard solutions $\left(1000 \mu \mathrm{g} \cdot \mathrm{mL}^{-1}\right)$ in $\mathrm{HNO}_{3}$ or $\mathrm{HCl}$ for ICP-MS or AAS were purchased from Merck (Singapore). Multielement working standard solution was prepared weekly by dilution of the stock solution in $5 \% \mathrm{HNO}_{3}$ in ultrapure water and kept at $4^{\circ} \mathrm{C}$ in an amber HDPE bottle.

For multielemental analysis: an ELAN 9000 ICP-MS (PerkinElmer Sciex, Penlivia Canada) system including a liquid autosampler was used for multielemental analysis. Sensitivity and performance of the ICP-MS instrument was daily checked by using tuning solution (Perkin Elmer).

\subsection{Sample Preparation}

2.3.1. Water Samples. After transporting to the laboratory, water samples were acidified with $\mathrm{H}_{2} \mathrm{SO}_{4}$ for As and $\mathrm{HNO}_{3}$ for other elements. Milli-Q water acidified with $\mathrm{H}_{2} \mathrm{SO}_{4}$ or $\mathrm{HNO}_{3}$ was used as control. Arsenic concentration in water samples was measured by hydride generation atomic absorption spectrometry (AAS) using a Shimadzu HVG-1 hydride system coupled to a Shimadzu-AA680 AAS [10]. Concentrations of $\mathrm{Cu}, \mathrm{Pb}, \mathrm{Cd}, \mathrm{Zn}, \mathrm{Co}, \mathrm{B}$, Se, $\mathrm{Mo}, \mathrm{Mn}, \mathrm{Sb}, \mathrm{Cr}$, $\mathrm{Ba}$, and $\mathrm{Fe}$ were determined by inductively coupled plasma mass spectrometry (ICP-MS; Hewlett-Packard, HP-4500) [11]. Indium was used as an internal standard for ICP-MS measurements. Water $\mathrm{pH}$ was measured by a glass electrode pH meter (Asahi Techno Glass).

2.3.2. Rice Samples. An approximately $0.2 \mathrm{~g}$ freeze-dried rice sample was weighed into a $75 \mathrm{~mL}$ Teflon microwave digestion vessel, and $6 \mathrm{~mL}$ of concentrated nitric acid was added and stood overnight. Afterward, rice sample was digested in a microwave oven (Multiwave PRO $50 \mathrm{HZ}$ Package 24HVT8, Anton Paar, Graz, Austria). The temperature program was increased up to $165^{\circ} \mathrm{C}$ in $15 \mathrm{~min}$ and then held at this temperature for a further $10 \mathrm{~min}$. In the second step of the digestion, the vessels were cooled to $50^{\circ} \mathrm{C}$ for 20 minutes. After digestion, the samples were cooled to room temperature and transferred quantitatively into $50 \mathrm{~mL}$ volumetric flasks and made up to volume with DIW. Solutions were analyzed for the total arsenic content by inductively coupled plasma-dynamic reaction cell quadrupole mass spectrometry (ICP-DRC-QMS) employing with oxygen gas in order to eliminate polyatomic interferences. For quality control and method validation, rice-based certificated reference material (ERM BC-211) was prepared and analyzed at the same time.

2.3.3. Serum and Urine Samples. The sample treatment procedure for As and other trace elements in urine, serum, and hair samples followed the method described in our previous study [12]. Urine and serum samples were digested in an acidic condition in a microwave oven for total As determination. In brief, $0.1 \mathrm{~mL}$ of urine or serum was poured into a microwave cell, and $2 \mathrm{~mL}$ concentrated nitric acid (Suprapure, Merck, Singapore) and $1 \mathrm{~mL} \mathrm{H}_{2} \mathrm{O}_{2}$ (Merck, Singapore) were added, followed by digestion at $80 \%$ power of an Anton PARR (Graz, Austria) microwave oven. After digestion, the clear solution was transferred to a precleaned $15 \mathrm{~mL}$ polypropylene tube and deionized water was added to $5 \mathrm{ml}$. These solutions were subjected to analysis by ICP-MS using indium as the internal standard. Fish-based matrixcertified reference material (DORM III and DORM IV from National Research Council, Canada and BRC 627, BRC 211 from Institute for Reference Materials and Measurements, 
TABLE 1: Information on groundwater and human samples analyzed in this study.

\begin{tabular}{|c|c|c|c|c|}
\hline Sample & Groundwater & Hair & Urine & Blood \\
\hline Sample number & $\begin{array}{l}21 \text { unfiltered water } \\
21 \text { filtered or rain water }\end{array}$ & 35 & 29 & 29 \\
\hline Water utilization time (year) & $16(10-26)$ & & & \\
\hline Age (year) & & $44(23-70)$ & $44(23-70)$ & $44(23-70)$ \\
\hline
\end{tabular}

Belgium) was used for quality control of total arsenic analysis. Practically, the number of quality control and blank samples accounted for $20 \%$ of the number of total samples that were subjected to total analysis.

2.3.4. Hair Samples. Human hair samples were washed by sonication with $0.5 \%$ surfactant reagent (polyoxyethylene lauryl ether) and subsequently dried for $12 \mathrm{~h}$ at $80^{\circ} \mathrm{CC}$. For As analysis, a dried hair sample was accurately weighted directly into a Kjeldahl flask and $8 \mathrm{ml}$ of purified $\mathrm{HNO}_{3}$ was added. After predigestion at room temperature overnight, the sample was treated with $16 \mathrm{ml}$ of acid mixture $\left(\mathrm{HNO}_{3}\right.$ : $\left.\mathrm{HClO}_{4}: \mathrm{H}_{2} \mathrm{SO}_{4} 1: 2: 1\right)$ and digested by heating to over $300^{\circ} \mathrm{C}$ until the perchloric acid was removed. Arsenic concentration was measured by HG-AAS. For analysis of other trace elements, about $0.1 \mathrm{~g}$ of the hair sample was digested in $1.5 \mathrm{ml}$ of concentrated $\mathrm{HNO}_{3}$ in a Teflon PTFE tube in a microwave oven with the same manner as with rice and serum and urine samples. Concentrations of 13 elements ( $\mathrm{Cu}, \mathrm{Pb}, \mathrm{Cd}, \mathrm{Zn}, \mathrm{Co}, \mathrm{B}, \mathrm{Se}, \mathrm{Mo}, \mathrm{Mn}, \mathrm{Sb}, \mathrm{Cr}, \mathrm{Ba}$, and $\mathrm{Fe}$ ) were determined by ICP-MS. The accuracy of the method was assessed using spiking experiments. Recoveries of the elements ranged from 80 to $118 \%$.

2.4. Statistical Analysis. Statistical analysis was performed using Microsoft Excel (Microsoft Office 2010) and Minitab $16{ }^{\circledR}$ Statistical Software (Minitab Inc.). The whole data set were analyzed by Pearson correlation analysis to find out possible relationships between the target compounds. The level of statistical significance was set at $p<0.05$.

\section{Results and Discussion}

3.1. Contamination of Arsenic and Other Trace Elements in Groundwater and Rice. Concentrations of arsenic in groundwater collected from tube wells of 20 families ranged from $<0.01$ to $467 \mu \mathrm{g} / \mathrm{l}$, with mean and median concentrations of 109 and $89.9 \mu \mathrm{g} / \mathrm{l}$, respectively (Table 2 ). Most of the unfiltered groundwater samples (20/21) contained As concentrations exceeding the WHO guideline value of $10 \mu \mathrm{g} / \mathrm{l}$ with the highest As concentration of $467 \mu \mathrm{g} / 1$ [13]. Water samples from the household containers of each family, which were mixed of filtrated groundwater and rain water, were also collected and examined. As concentrations in filtered groundwater and rain water were remarkably reduced as compared with those in untreated groundwater, ranging from 1.12-135 $\mu \mathrm{g} / \mathrm{l}$ (mean: $44.2 \mu \mathrm{g} / \mathrm{l}$ ).

It should be noted that $70 \%$ of filtered water samples $(14 / 21$ samples) contained As concentrations exceeding the WHO guideline value. This result indicates that As contamination in
Ha Nam province is still relatively serious. As concentrations in Nhat Tan village were higher than those reported in several sites in Ha Nam province (Liem Thuan and Nhan Dao), in some districts of Hanoi city (Gia Lam, Dong Anh, and Tu Liem), but lower than those from Bo De, Hoa Hau, and Vinh Tru in the province $[6,8]$. As concentrations in Nhat Tan were still lower than those in Chuyen Ngoai and Chau Giang village of Ha Nam province [9]. Many of the sand-filtered groundwater samples still contained elevated As concentrations. Our data is consistent with that from a previous study, suggesting that a household sand filtration system is not efficient enough to reduce As contamination to the safe level [9].

Concentrations of other elements in groundwater are given in Table 2. Concentrations of $\mathrm{Fe}, \mathrm{Ba}, \mathrm{Mo}$, and $\mathrm{B}$ were higher than other elements. Meanwhile, toxic heavy metals such as $\mathrm{Pb}, \mathrm{Zn}$, and $\mathrm{Cd}$ showed relatively low contamination levels. Mean concentrations of $\mathrm{Sb}, \mathrm{Mn}$, and $\mathrm{Ba}$ in groundwater from Nhat Tan were 25.7, 23.8, and $2380 \mu \mathrm{g} / \mathrm{l}$, respectively. About $50 \%$ of groundwater samples contained $\mathrm{Sb}$ concentrations exceeding the WHO drinking water guideline value of $5 \mu \mathrm{g} / \mathrm{l}$. As for $\mathrm{Ba}$, concentrations ranged from 0.47-91600 $\mu \mathrm{g} / \mathrm{l}$ (mean: $2380 \mu \mathrm{g} / \mathrm{l}$ ), with two samples having elevated concentrations exceeding the WHO guideline value $(700 \mu \mathrm{g} / \mathrm{l})$. Mn concentrations were from $<0.01$ to $257 \mu \mathrm{g} / \mathrm{l}$, and no sample had concentrations beyond the WHO guideline level. Our previous study from other villages in $\mathrm{Ha}$ Nam province also showed similar contamination levels and distribution, with elevated concentrations of As and Ba with significant numbers of samples having concentrations exceeding the WHO guideline value [9]. This fact suggests widespread contamination of As and other trace elements such as $\mathrm{Mn}$ and $\mathrm{Ba}$ from $\mathrm{Ha}$ Nam province.

Concentrations of As in rice collected from each family along with groundwater ranged from 0.05 to $0.33 \mu \mathrm{g} / \mathrm{g}$, mean: $0.09 \mu \mathrm{g} / \mathrm{g}$. Fe, $\mathrm{Zn}$, and Mo showed higher concentrations than other elements. $\mathrm{Cu}, \mathrm{Pb}$, and $\mathrm{Ba}$ were at moderate levels, ranging from 4.9 to $5.5 \mu \mathrm{g} / \mathrm{g}$. In $\mathrm{Ha}$ nam Province, As concentrations in rice from Nhat Tan were lower higher than those reported in Vinh Tru, Ha Tay, Hanoi [6], and some locations in the Red River Delta [14].

3.2. Contamination by As and Other Elements in Human Samples. Concentrations of As in hair and urine of people of 21 families consuming groundwater ranged from 0.1 to $2.5 \mu \mathrm{g} / \mathrm{g}$ (mean: $0.59 \mu \mathrm{g} / \mathrm{g}$ ) and 0.7 to 28.1 (mean: $5.12 \mu \mathrm{g} / \mathrm{g}$ creatinine), respectively (Table 2 ). As concentrations in groundwater significantly correlated with those in both hair and urine of male samples $(r=0.63 ; p<0.05)$. Similar significant correlations were observed between groundwater and hair of human-consumed As-contaminated water from 


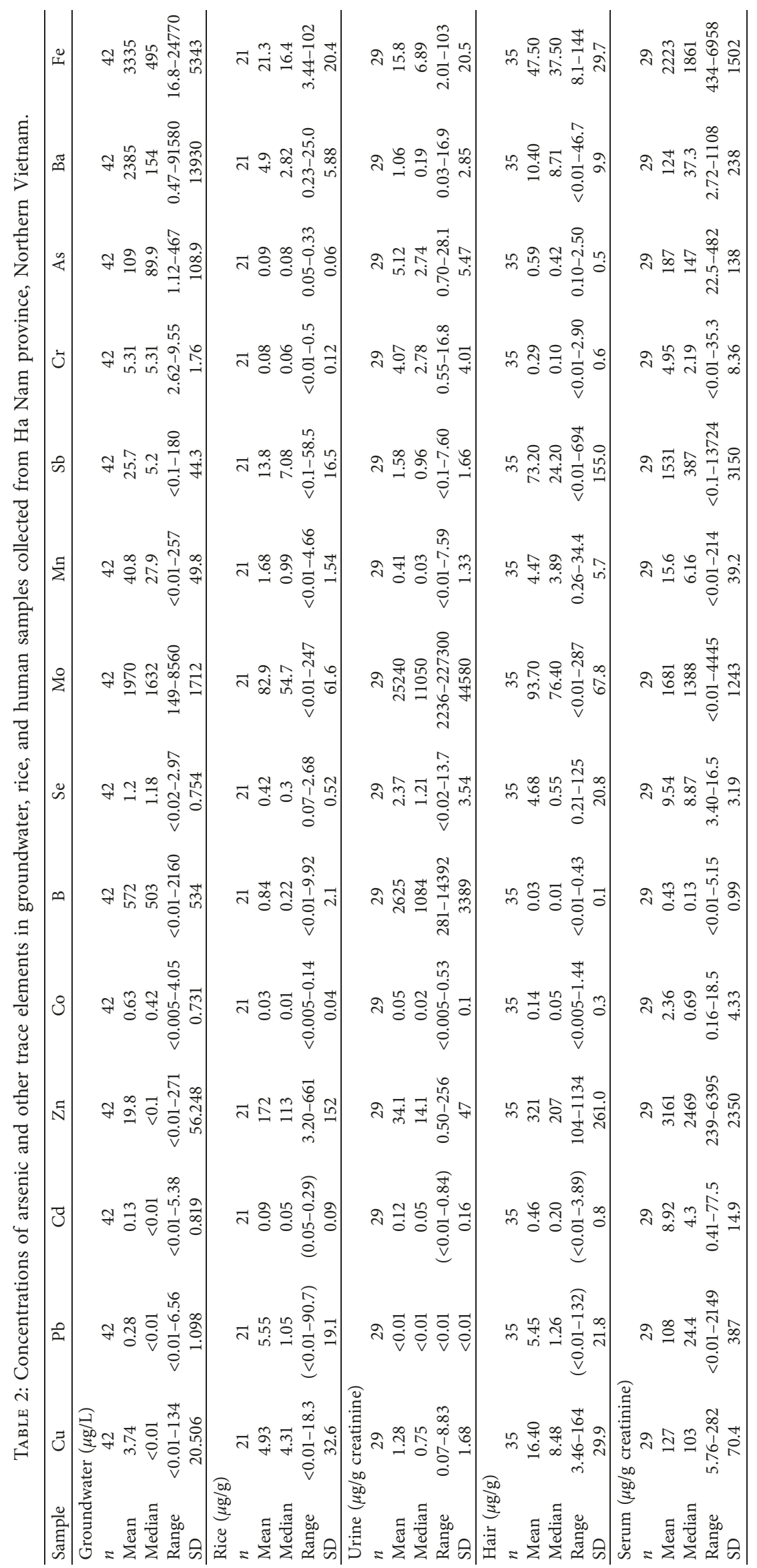


suburban areas of Hanoi and 4 villages of Ha Nam province $[8,15]$. This result continues to support long-term chronic exposure to As through consumption of contaminated groundwater. The As levels in hair and urine were generally in the range to those reported in Hoa Hau, Liem Thuan, Bo De, Chuyen Ngoai, and Chau Giang villages in Ha Nam province $[6,8,9]$. Our data in Nhat Tan village further indicate widespread groundwater contamination and chronic human exposure to As in Ha Nam province.

To evaluate the possible factors influencing As contamination in human samples, As exposure in hair and urine according to the groundwater usage was examined (Figure 1). An interesting result was observed, showing higher degree of contamination in hair and urine of people using groundwater for drinking as compared with washing. Unlike other locations such as Bangladesh, the groundwater usage habit in Vietnam varied among locations and families. Our questionnaire survey indicated that there are two main groups: one using water for drinking and washing and the other mainly using groundwater for washing and rain water for drinking. Higher As concentrations in hair and urine samples of the drinking group clearly suggest that the major pathway of As exposure in the investigated groups is via the contaminated groundwater. In hair samples, there are 4 samples containing As concentrations greater than the level associated with skin disease of $1 \mu \mathrm{g} / \mathrm{g}$ [16].

Among trace elements, $\mathrm{Ba}, \mathrm{Mo}, \mathrm{Sb}$, and $\mathrm{Zn}$ accumulated higher levels than the others (Table 2). Concentrations of $\mathrm{Pb}$ and $\mathrm{Cd}$ in urine were relatively low. Their residue levels in hair and serum ranged from $<0.01$ to 132 and $<0.01$ to $3.89 \mu \mathrm{g} / \mathrm{g}$, respectively, while $\mathrm{Cu}$ and $\mathrm{Zn}$ accumulated higher concentrations than $\mathrm{Pb}$ and $\mathrm{Cd}$. As for $\mathrm{Ba}$, despite elevated concentrations in groundwater, concentrations in hair and urine were at moderate levels. Mn concentrations in hair samples were $0.26-34.4 \mu \mathrm{g} / \mathrm{g}$, mean: $4.47 \mu \mathrm{g} / \mathrm{g}$. Only one hair sample contained Mn concentrations exceeding the levels associated with chronic Mn poisoning [17, 18]. However, given the elevated concentrations of $\mathrm{Mn}$ and $\mathrm{Ba}$ in some human samples, the toxic effects of these elements are of concern, and further studies are needed to provide in-depth assessment of relationship between their human exposure and toxic effects.

As concentrations in serum samples ranged from 22.5 to $482 \mu \mathrm{g} / \mathrm{g}$ creatinine $(1.09-25.2 \mu \mathrm{g} / \mathrm{l}$, mean: $11.2 \mu \mathrm{g} / \mathrm{l})$. There are almost no data available for As in blood samples from groundwater contaminated areas in Vietnam. Our data in Ha Nam province was comparable with those reported in national survey in Bangladesh and slightly lower than the mean blood level of people identified with skin lesion $(14.3 \mu \mathrm{g} / \mathrm{l}, n=303)$ [19]. The serum As concentrations in Vietnam were higher than those in both healthy people and patients with various diseases reported in Belgium [20]. As for other elements, mean concentrations of $\mathrm{Pb}$ and $\mathrm{Cd}$ were from 6.44 to $0.52 \mu \mathrm{g} / \mathrm{l}$, respectively, which were comparable or higher than those reported for patients with acute hemorrhagic stroke in Turkey [21]. In general, toxic element concentrations in serum from Ha Nam were in the range of those reported in human samples with toxic element-associated diseases. Further studies are therefore needed to evaluate long-term accumulation and relationship between levels of As and other toxic elements from As-contaminated areas in Vietnam.

3.3. Exposure Assessment of As and Other Trace Elements. To further evaluate the accumulation and source of exposure of As and trace elements, correlations between various kinds of samples (water, rice, urine, hair, and serum) were examined, and the result of the significant relationships is given in Table 3. Significant correlations between As water and As urine and hair in males were observed. As for rice samples, good correlations were also recorded in male and female hair and female urine. Serum and urine As in males and females showed significant correlations. Levels in urine and hair reflect current and long-term exposure. All these observations suggest the chronic exposure to As through consumption of water and rice. Similar results with significant positive correlations between As concentrations in groundwater and As concentrations in urine and hair from various villages from $\mathrm{Ha}$ Nam $[6,8,20]$. In the present study, we provide more comprehensive data with As exposure to different kinds of samples including water and rice and three types of human samples.

To evaluate the risk for cumulative exposure to As, Mn, and $\mathrm{Ba}$ through contaminated groundwater, we estimated intakes of these elements based on the age of wells, annual ingestion rate of groundwater, and daily water consumption. The detailed descriptions for calculation of cumulative intakes are described in Agusa et al. [15]. The cumulative intakes (CI) and daily intakes (DI) of As, $\mathrm{Mn}$, and Ba were estimated for residents in the studied area based on the following equations $[6,15]$ :

$$
\begin{aligned}
& \text { CI }(\mu \mathrm{g})=\text { Concentration of element in groundwater }(\mu \mathrm{g} / \mathrm{L}) \\
& \times \text { Water utilization time (year) } \\
& \times \text { Annual ingestion rate of groundwater (day/year) } \\
& \times \text { Water consumption rate (L/day), } \\
& \text { DI }(\mu \mathrm{g} / \text { day })=\text { Concentration of element in groundwater }(\mu \mathrm{g} / \mathrm{L}) \\
& \times \text { Water consumption rate (L/day) } \\
& + \text { Concentration of element in rice }(\mu \mathrm{g} / \mathrm{g}) \\
& \times \text { Rice consumption rate (g/day). }
\end{aligned}
$$

The annual ingestion rate of groundwater was assigned as 182.5 days per year, implying the use of groundwater during dry seasons [15]. The water consumption rate was $2 \mathrm{~L} /$ day [13]. A rice consumption rate of $369.1 \mathrm{~g} /$ day for the Red River Delta region was retrieved from the General Nutrition Survey from 2009 to 2010 [22]. The daily intake doses (DID, $\mu \mathrm{g} / \mathrm{kg} /$ day) of these elements were calculated by the abovementioned DI values with an average body weight of $50 \mathrm{~kg}$ and compared with the tolerable daily intakes (TDIs) proposed by the World Health Organization (WHO) [23].

We found significant positive correlations between cumulative intakes of $\mathrm{As}, \mathrm{Mn}$, and $\mathrm{Ba}$ and their concentrations in human hair (Figure 2). A similar result was observed in a 


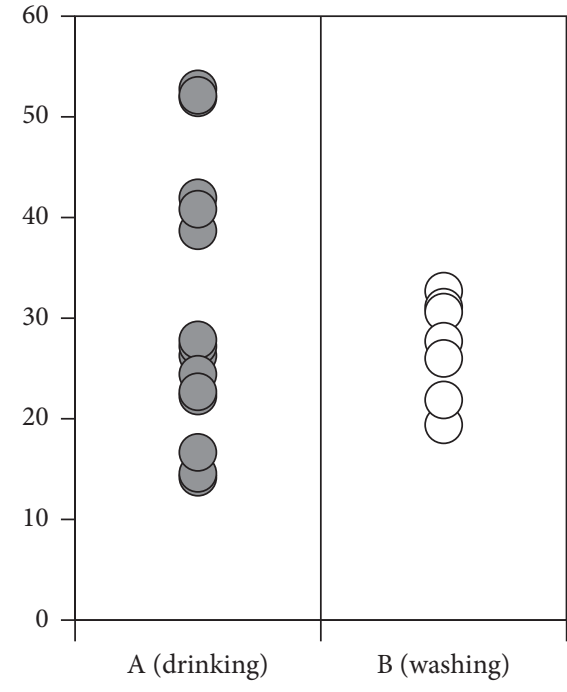

(a)

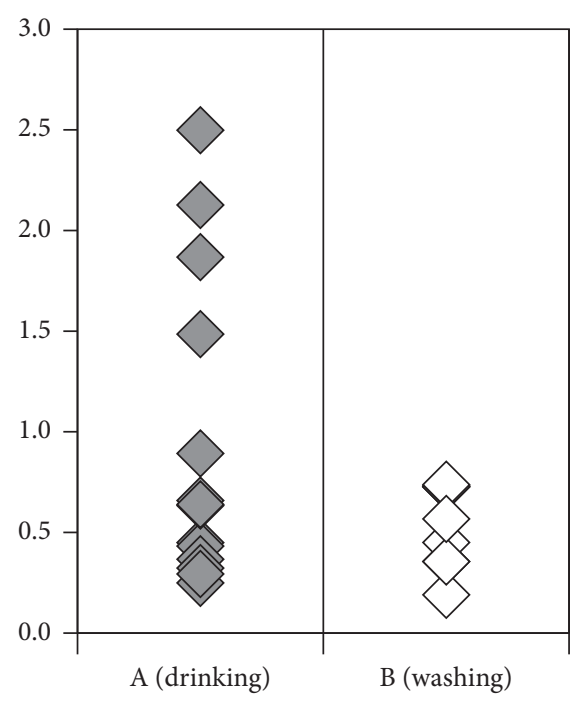

(b)

Figure 1: Concentrations of As in urine and hair samples of two groups using groundwater for drinking (A) and washing (B). Exposure levels of group A were significantly higher than those of group B (Mann-Whitney $U$ test, $p<0.05)$. (a) As concentration in urine $(\mu \mathrm{g} / \mathrm{l})$. (b) As concentration in hair $(\mu \mathrm{g} / \mathrm{g})$.

TABLE 3: Results of statistical analyses for the correlations between As concentrations in different kinds of samples.

\begin{tabular}{lcc}
\hline Paired samples & Correlation coefficient $R$ & $p$ value \\
\hline Water-male urine & 0.605 & 0.049 \\
Water-male hair & 0.626 & 0.039 \\
Rice-female hair & 0.941 & 0.001 \\
Rice-male hair & 0.686 & 0.02 \\
Rice-female urine & 0.755 & 0.007 \\
Female hair-female urine & 0.654 & 0.029 \\
\hline
\end{tabular}

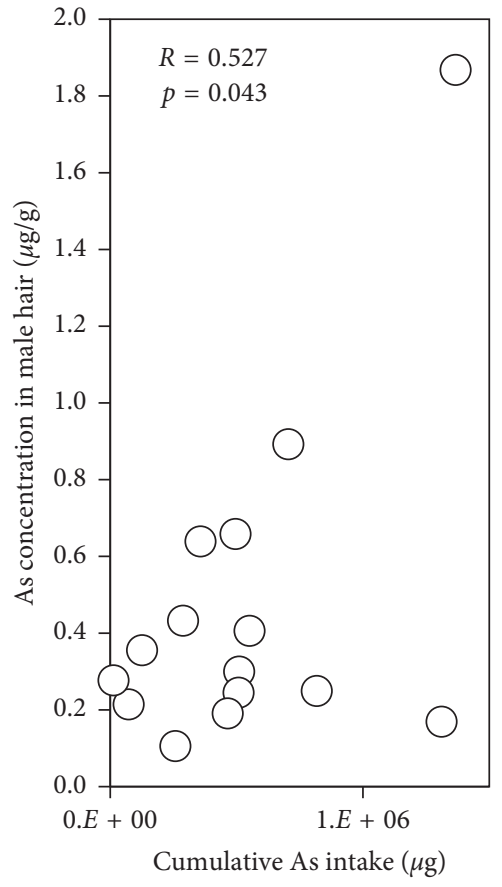

(a)

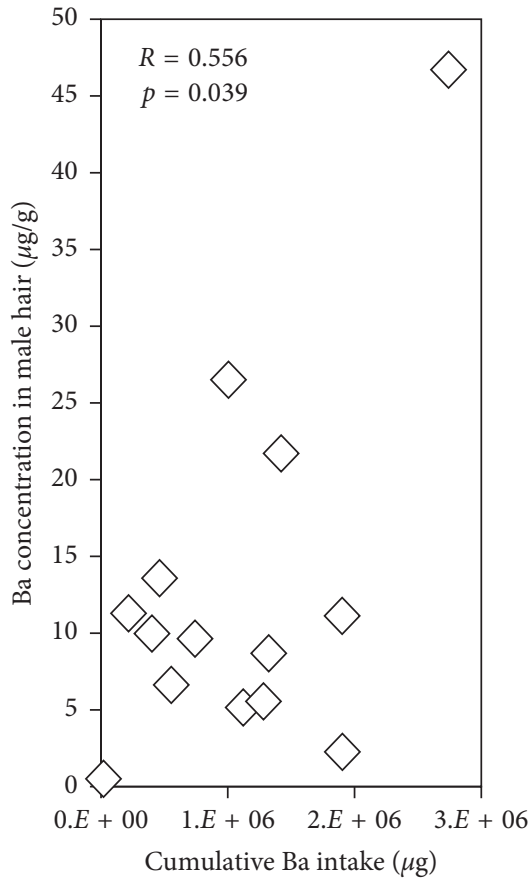

(b)



(c)

FIgURE 2: Relationships between the cumulative intakes of (a) As, (b) Ba, and (c) Mn through contaminated groundwater and their concentrations in human hair samples (Pearson correlation coefficients $R>0.500, p<0.05$ ). 
TABle 4: Daily intakes ( $\mu \mathrm{g} /$ day) of As, Mn, and Ba through consumption of groundwater and rice estimated for residents in Nhat Tan Village, Ha Nam Province.

\begin{tabular}{lcccc}
\hline & & Water consumption & Rice consumption & Total daily intakes \\
\hline \multirow{2}{*}{ As } & Mean \pm SD & $218 \pm 130$ & $139 \pm 145$ & $357 \pm 220$ \\
& Range & $2.76-471$ & $3.04-578$ & $80.0-836$ \\
\hline \multirow{2}{*}{ Mn } & Mean \pm SD & $81.7 \pm 62.0$ & $621 \pm 581$ & $702 \pm 572$ \\
& Range & $1.92-258$ & $30.0-1720$ & $49.3-1850$ \\
\hline \multirow{2}{*}{ Ba } & Mean \pm SD & $4770 \pm 20,000$ & $1800 \pm 2230$ & $6580 \pm 20,800$ \\
& Range & $4.13-92,000$ & $83.6-9230$ & $311-97,100$ \\
\hline
\end{tabular}

previous survey in Hanoi suburban areas and some villages in Ha Nam $[9,15]$. Our data suggest that people living the investigated area in $\mathrm{Ha} \mathrm{Nam}$ province are chronically exposed to As, $\mathrm{Mn}$, and $\mathrm{Ba}$ through consumption of contaminated groundwater.

In addition to exposure through groundwater, intakes through rice is considered to be an important pathway because rice is one of the major foods for Vietnamese people. Paired samples of rice and groundwater of investigated families are available for estimation of total intakes of trace elements. Means and ranges of total intake of As, Mn, and $\mathrm{Ba}$ through rice and groundwater consumption are given in Table 4 . The detailed description of estimation of total intakes is described in Agusa et al. [6]. The total intakes of As, $\mathrm{Mn}$, and $\mathrm{Ba}$ were in the range of $80-836,49.3-1850$, and 311-97110 $\mathrm{g} /$ day, respectively. In particular, the mean As intake was $357 \mu \mathrm{g} /$ day, which was lower than those previously estimated in As-contaminated sites in Vietnam, but comparable or higher than those in some places in Bangladesh [20, 24].

However, the As intakes were apparently higher than those in noncontaminated sites $[25,26]$. The intake values of As estimated per 1 kilogram of body weight were ranged from $1.6-16.7 \mu \mathrm{g} / \mathrm{kg} \cdot$ body wt./day, mean: $7.15 \mu \mathrm{g} / \mathrm{kg} \cdot$ body wt./day. Daily intakes for about $80 \%$ the subjects were above the provisional tolerable intake value proposed by the WHO (3 $\mu \mathrm{g} / \mathrm{kg}$.body wt./day) [23]. This fact raises concern over the elevated chronic exposure to As and suggests the needs for continued comprehensive surveys in a larger geographical area in Vietnam.

Health risks for human were evaluated from values of chronic risk and carcinogenic risk. The value of chronic risks can be calculated by the ratio between the estimated exposure (average daily intake-ADD) and the reference dose (RfD) called the "Hazard Quotient" (HQ).

$$
\mathrm{HQ}=\frac{\mathrm{ADD}}{\mathrm{RfD}} \text {. }
$$

The risk is considered when HQs $>1$.

Besides, carcinogenic risk can be calculated as follows:

$$
\mathrm{R}=1-\mathrm{e}^{-(\mathrm{SF} \times \mathrm{ADD})}
$$

where SF is the slop factor. The detailed description of the risk assessment using HQ and SF is given in our previous study [9].

As the results of high arsenic consumption through the drinking water pathway, both potential chronic and carcinogenic risks of the two groups were calculated. Approximately,
$52 \%$ of the families using filtered groundwater and $86 \%$ of the families using unfiltered groundwater could be affected by arsenic. The value of carcinogenic risk index for residents using unfiltered and filtered groundwater was estimated to be 3 in 1,000 people and 8 in 10,000 people. While the ratio of 1 in $1,000,000$ is considered to be significant by the US-EPA, the carcinogenic rate values estimated above suggest high potential risk.

\section{Conclusion}

In summary, the present study continues to indicate elevated and widespread contamination by As in groundwater in $\mathrm{Ha}$ Nam province. Residents living in the investigated area are chronically exposed to As, Mn, and Ba. Estimated daily intakes of As were still relatively high, with significant numbers of subjects exceeding the WHO tolerable intake value. Further monitoring on the As speciation in groundwater and human samples and toxicologic studies along with development of effective treatment technologies to reduce As levels in groundwater is urgently needed to mitigate risk for elevated and chronic As exposure.

\section{Data Availability}

The data used to support the findings of this study are included within the article.

\section{Conflicts of Interest}

The authors declare that they have no conflicts of interest.

\section{Acknowledgments}

This research was funded by the Vietnam National University-Hanoi under project number QG.17.17.

\section{References}

[1] U. K. Chowdhury, B. K. Biswas, T. R. Chowdhury et al., "Groundwater arsenic contamination in Bangladesh and West Bengal, India," Environmental Health Perspectives, vol. 108, no. 5, pp. 393-397, 2000.

[2] H. M. Anawar, J. Akai, K. M. G. Mostofa, S. Safiullah, and S. M. Tareq, "Arsenic poisoning in groundwater: health risk and geochemical sources in Bangladesh," Environment International, vol. 27, no. 7, pp. 597-604, 2002.

[3] G. Marshall, C. Ferreccio, Y. Yuan et al., "Fifty-Year study of lung and bladder cancer mortality in Chile related to arsenic 
in drinking water," JNCI Journal of the National Cancer Institute, vol. 99, no. 12, pp. 920-928, 2007.

[4] Y.-K. Huang, Y.-L. Huang, Y.-M. Hsueh, J. T.-J. Wang, M.-H. Yang, and C.-J. Chen, "Changes in urinary arsenic methylation profiles in a 15-year interval after cessation of arsenic ingestion in Southwest Taiwan," Environmental Health Perspectives, vol. 117, no. 12, pp. 1860-1866, 2009.

[5] M. Berg, H. C. Tran, T. C. Nguyen, H. V. Pham, R. Schertenleib, and W. Giger, "Arsenic contamination of groundwater and drinking water in Vietnam: a human health threat," Environmental Science \& Technology, vol. 35, no. 13, pp. 2621-2626, 2001.

[6] T. Agusa, T. Kunito, R. Kubota et al., "Exposure, metabolism, and health effects of arsenic in residents from arsenic-contaminated groundwater areas of Vietnam and Cambodia: a Review," Reviews on Environmental Health, vol. 25, no. 3, pp. 193-220, 2010.

[7] M. N. Dang, K. H. Nguyen, B. Chander, and Q. H. Nguyen, "The Adverse Effects of Arsenic on Population Health in Selected Communities of Ha Nam Province," in Proceedings of the Workshop of Science and Technology Relating to Arsenic Contamination, Hanoi, Vietnam, 2012.

[8] V. A. Nguyen, S. Bang, P. H. Viet, and K.-W. Kim, "Contamination of groundwater and risk assessment for arsenic exposure in Ha Nam province, Vietnam," Environment International, vol. 35, no. 3, pp. 466-472, 2009.

[9] L. H. Pham, H. T. Nguyen, C. Van Tran, H. M. Nguyen, T. H. Nguyen, and M. B. Tu, "Arsenic and other trace elements in groundwater and human urine in $\mathrm{Ha}$ Nam province, the Northern Vietnam: contamination characteristics and risk assessment," Environmental Geochemistry and Health, vol. 39, no. 3, pp. 517-529, 2017.

[10] T. Agusa, T. Kunito, R. Kubota, I. Monirith, S. Tanabe, and T. S. Tana, "Arsenic pollution in Cambodia," Biomedical Research on Trace Elements, vol. 13, pp. 254-255, 2002.

[11] T. Agusa, T. Kunito, E. Nakashima et al., "Preliminary studies on trace element contamination in dumping sites of municipal wastes in India and Vietnam," Journal de Physique IV (Proceedings), vol. 107, pp. 21-24, 2003.

[12] M. H. Nguyen, T. D. Pham, T. L. Nguyen et al., "Speciation analysis of arsenic compounds by HPLC-ICP-MS: application for human serum and urine," Journal of Analytical Methods in Chemistry, vol. 2018, Article ID 9462019, 2018.

[13] World Health Organization, Guidelines for Drinking Water Quality, World Health Organization International Program on Chemical Safety, Geneva, Switzerland, 1998.

[14] T. D. Phuong, S. Kokot, P. V. Chuong, and D. Tong Khiem, "Elemental content of Vietnamese ricePart 1. Sampling, analysis and comparison with previous studies," The Analyst, vol. 124, no. 4, pp. 553-560, 1999.

[15] T. Agusa, T. Kunito, J. Fujihara et al., "Contamination by arsenic and other trace elements in tube-well water and its risk assessment to humans in Hanoi, Vietnam," Environmental Pollution, vol. 139, no. 1, pp. 95-106, 2006.

[16] H. L. Arnold, R. B. Odom, W. D. James et al., Andrew's Diseases of the Skin: Clinical Dermatology, WB Saunders Company, Philadelphia, Pa, USA, 8th edition, 1990.

[17] X. G. Kondakis, N. Makris, M. Leotsinidis, M. Prinou, and T. Papapetropoulos, "Possible health effects of high manganese concentration in drinking water," Archives of Environmental Health: An International Journal, vol. 44, no. 3, pp. 175-178, 1989.

[18] A. Woolf, R. Wright, C. Amarasiriwardena, and D. Bellinger, "A child with chronic manganese exposure from drinking water," Environmental Health Perspectives, vol. 110, no. 6, pp. 613-616, 2002.

[19] M. Hall, Y. Chen, H. Ahsan et al., "Blood arsenic as a biomarker of arsenic exposure: results from a prospective study," Toxicology, vol. 225, no. 2-3, pp. 225-233, 2006.

[20] T. Agusa, T. Kunito, T. B. Minh et al., "Relationship of urinary arsenic metabolites to intake estimates in residents of the Red River Delta, Vietnam," Environmental Pollution, vol. 157, no. 2, pp. 396-403, 2009.

[21] S. Karadas, R. Sayın, M. Aslan et al., "Serum levels of trace elements and heavy metals in patients with acute hemorrhagic stroke," The Journal of Membrane Biology, vol. 247, no. 2, pp. 175-180, 2014.

[22] Ministry of Health (MOH), National Institute of Nutrition Vietnam. General Nutrition Survey 2009-2010, Medical Publishing House, Hanoi, Vietnam, 2010.

[23] World Health Organization (WHO), Exposure to Arsenic: A Major Public Health Concern, WHO, Geneva, Switzerland, 2010.

[24] M. L. Kile, E. A. Houseman, C. V. Breton et al., "Dietary arsenic exposure in Bangladesh," Environmental Health Perspectives, vol. 115, no. 6, pp. 889-893, 2007.

[25] O. P. Diaz, I. Leyton, O. Munoz et al., "Contribution of water, bread, and vegetables (raw and cooked) to dietary intake of inorganic arsenic in a rural village of Northern Chile," The Journal of Agricultural and Food Chemistry, vol. 52, no. 6, pp. 1773-1779.

[26] L. M. Del Razo, G. G. Garcia-Vargas, J. Garcia-Salcedo et al., "Arsenic levels in cooked food and assessment of adult dietary intake of arsenic in the Region Lagunera, Mexico," Food and Chemical Toxicology, vol. 40, no. 10, pp. 1423-1431, 2002. 

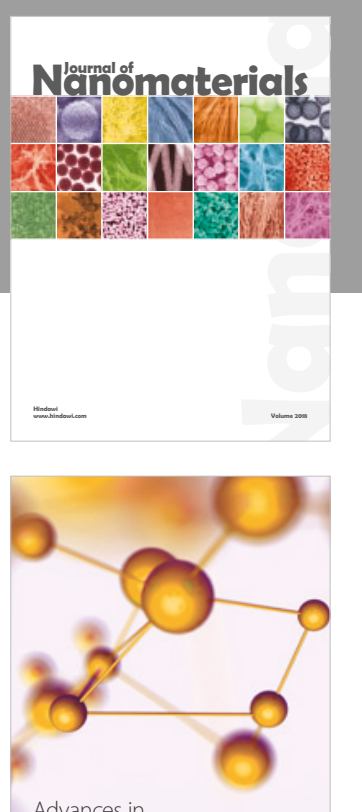

Physical Chemistry
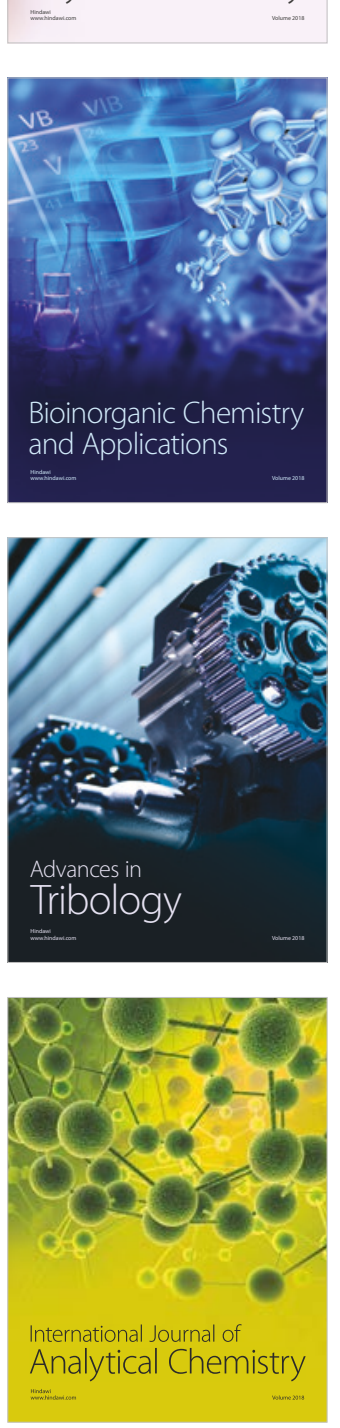

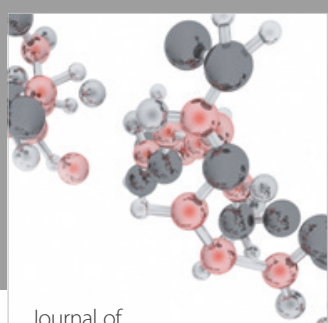

Analytical Methods

in Chemistry

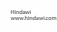

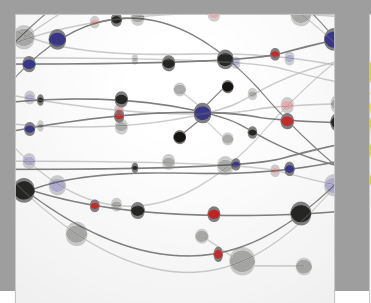

The Scientific World Journal

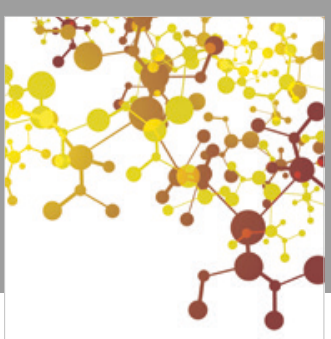

Journal of

Applied Chemistry
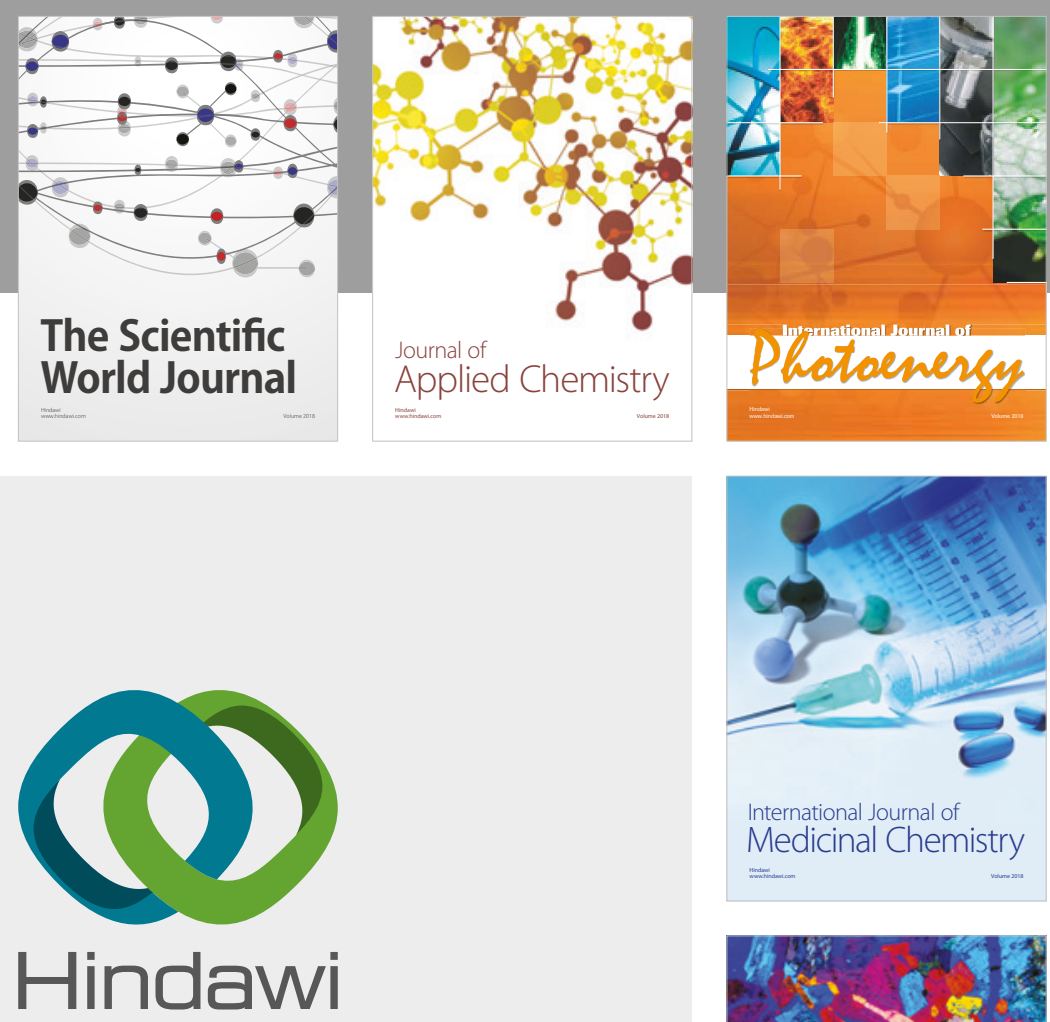

Submit your manuscripts at

www.hindawi.com
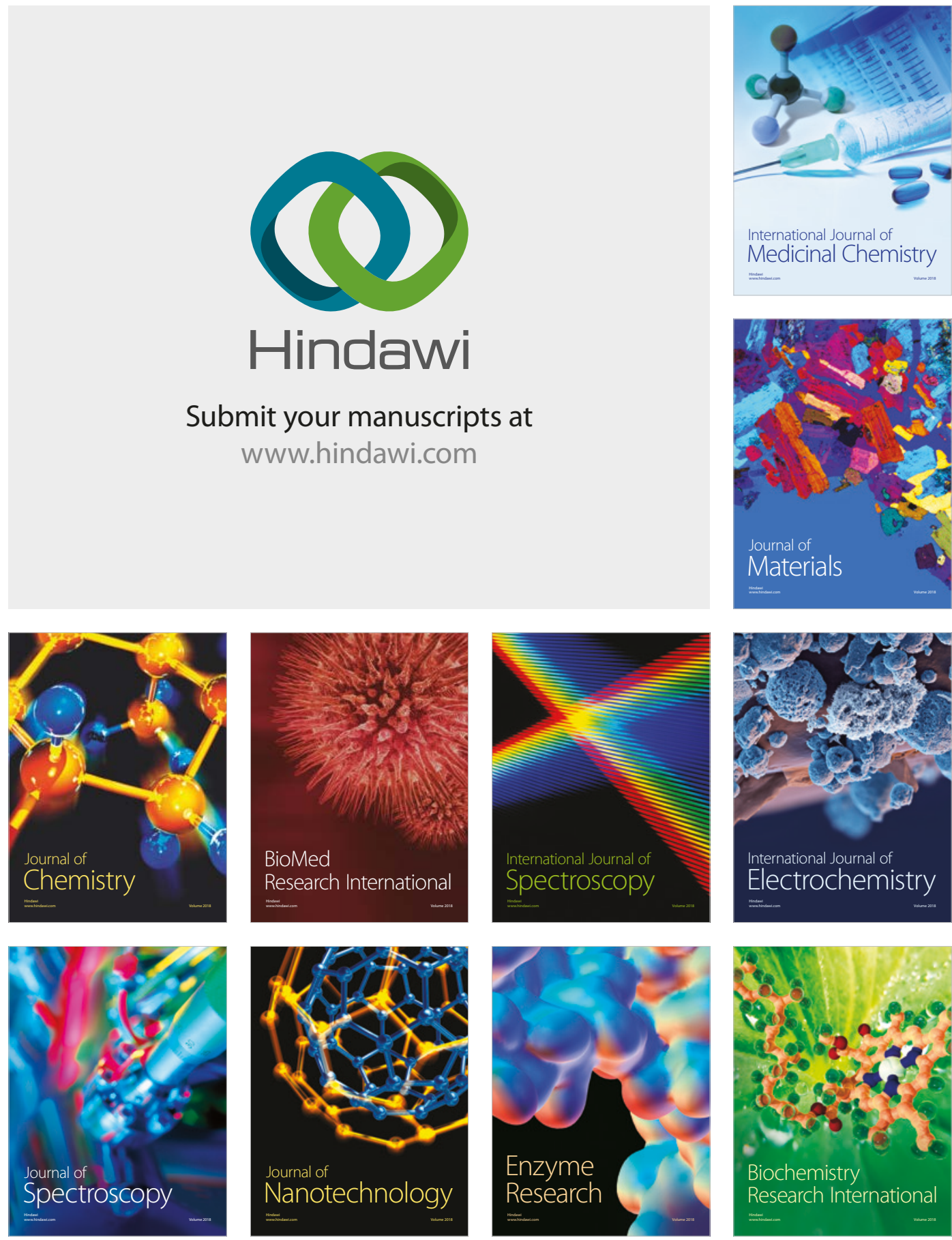
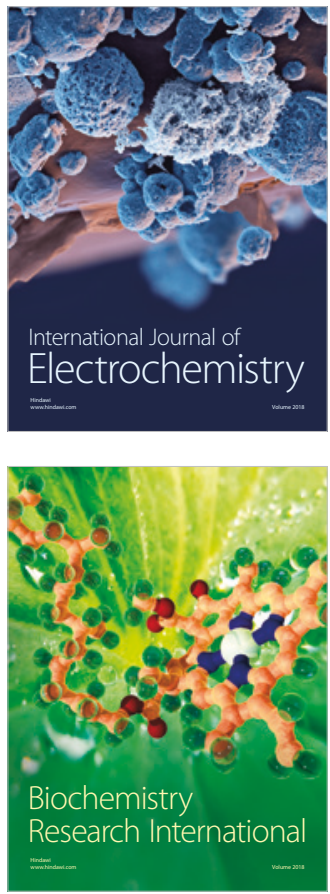